\title{
MODEL PENDIDIKAN KETERAMPILAN HIDUP (LIFE SKILLS) BAGI ANAK PUTUS SEKOLAH KORBAN LUMPUR LAPINDO
}

\author{
Sutini \\ Pardamean Daulay
}

\begin{abstract}
ABSTRAK
Artikel ini bertujuan mendeskripsikan hasil penelitian pengembangan model pendidikan keterampilan hidup (life skills) bagi anak putus sekolah korban lumpur Lapindo.

Pengumpulan data anak putus sekolah dan jenis keterampilan hidup yang diinginkan dilakukan melalui metode wawancara dan kuesinoer. Sementara pengembangan model pendidikan keterampilan hidup menggunakan metode penelitian dan pengembangan dengan memodifikasi model Plomp. Data dianalisis secara deskriptif persentase dan ratarata dan analisis kualitatiof model Miles dan Huberman (1992). Hasil penelitian menunjukkan bahwa karakteristik anak putus sekolah korban lumpur Lapindo di desa Renojoyo dan Siring kecamatan Porong, desa Besuki dan Pejarakan Kecamatan Jabon, dan desa Kedungbendo dan Sentul kecamatan Tanggulangin berjumlah 67 orang. Dari jumlah tersebut sebagian besar berpendidikan SLTA atau sederajat, yakni 30 orang atau $44,78 \%$, sedangkan 26 orang atau 38,80\% lulusan SMP atau sederajat, dan 11 orang atau $16,41 \%$ lulusan SD atau sederajat. Sebagian besar berusia antara 16 sampai usia 18 tahun, yakni 39 orang $(58,20 \%)$. Jenis keterampilan yang diinginkan adalah service sepeda motor, menjahit, service handphone, dan home industri. Untuk memindaklanjuti keinginan anak putus sekolah korban lumpur Lapindo (APSKLL) tersebut, dikembangkan tiga modul pendidikan keterampilan hidup, yakni modul service sepeda motor, modul keterampilan menjahit, dan modul service handphone. Penulisan modul dibuat sesederhana mungkin, isi materi yang mendasar, pilihan kata disesuaikan dengan tingkat pendidikan, serta dilengkapi ilustrasi berupa contoh dan gambar-gambar yang jelas. Namun, modul tersebut belum diujicoba karena itu sebelum dipergunakan dalam pelatihan pendidikan keterampilan hidup bagi APSKLL disarankan untuk melakukan penelitian ujicoba penggunaan modu.
\end{abstract}

Kata kunci: anak putus sekolah, korban lumpur, pendidikan keterampilan hidup

\begin{abstract}
This article aims to describe the development of models of educational research skills (life skills) for school dropouts Lapindo mudflow victims. Collecting data dropouts and the desired type of life skills is done through interviews and kuesinoer. While the development of life skills education model using the methods of research and development by modifying the model Plomp. Data were analyzed descriptively and the average percentage and kualitatiof analysis model of Miles and Huberman (1992). The results showed that the characteristics of school dropouts in the Lapindo mudflow victims Siring village and sub-district Renojoyo Porong, Besuki village and Pejarakan Jabon subdistrict, and village districts Sentul Tanggulangin Kedungbendo and numbered 67 people. Of these the majority of high school education or equivalent, ie 30 people or $44.78 \%$, while 26 people or $38.80 \%$ junior high school graduates, and 11 people, or $16.41 \%$ of primary school graduates or equivalent. Mostly aged between 16 and 18 years of age, ie 39 (58.20\%). Type the desired skills are service motorcycles, sewing, mobile phone service, and home industries. Memindaklanjuti
\end{abstract}


desire for school dropouts Lapindo mudflow victims (APSKLL), the three modules developed life skills education, the service module motorcycles, sewing skills module, and mobile phone service modules. Writing module is made as simple as possible, the basic material content, word choice tailored to the educational level, and comes in the form of examples and illustrative pictures are clear. However, the module has not been tested because it was before used in the training of life skills education for APSKLL advisable to conduct research trials modu use.

Keywords: life skills education, school dropouts, victims of the mud

Peristiwa meluapnya lumpur Lapindo di Sidoarjo sejak 29 Mei 2006 merupakan fenomena yang khas dan menimbulkan berbagai kontroversi baik dari sisi penyebab, lama kejadian, penanganan, maupun sikap pemerintah terhadap para korban. Sejak munculnya lumpur dan menenggelamkan desa-desa di sekitarnya, warga korban terpaksa harus pindah ke daerah baru karena tidak mungkin kembali ke lingkungan asalnya, bahkan kondisi ini dilegalisasi melalui Perpres 14/2007 dan Perpres 48/2008 yang memerintahkan korban untuk menjual tanah dan bangunan mereka ke PT. Lapindo (Novenanto, 2012).

Apapun faktor penyebabnya, semburan lumpur panas telah mengakibatkan kerugian bagi korban tidak hanya sebatas pada persoalan fisik lingkungan yang berada di sekitar wilayah bencana, tetapi juga aspek sosial budaya, baik secara perlahan-lahan maupun dalam bentuk yang cepat. Hasil penelitian Daulay dan Singgih (2012) tentang pola kehidupan dan kesempatan kerja migran petani korban lumpur Lapindo di daerah tujuan menunjukkan bahwa kehidupan ekonomi rumahtangga migran cukup memprihatinkan. Mereka tidak hanya kehilangan pekerjaan, tetapi juga kesulitan membiayai pendidikan anak-anak. Pengangguran semakin membengkak, lulusan sekolah semakin sulit mencari pekerjaan, sehingga orang tua menginginkan anaknya untuk bekerja agar mendatangkan hasil.

Sementara itu, menurut data Posko Informasi Keselamatan Korban Lumpur Lapindo (2010) bahwa tiap mendekati tahun ajaran baru, ratusan anak-anak korban lumpur Lapindo tidak menentu masa depannya, apakah dapat melanjutkan sekolah atau tidak. Bahkan, tidak jarang diantaranya terpaksa harus putus sekolah karena orang tuanya tidak mampu lagi membiayai pendidikan dan kehidupan mereka sehari-hari. Gejala yang muncul sebagian besar terjadi pada peserta anak didik tingkat SMP yang tidak melanjutkan ke jenjang pendidikan SLTA, namun ada juga yang hanya bersekolah sampai tingkat SD. Di sisi lain, Bantuan Operasional Sekolah (BOS) yang seharusnya dapat menjadi alat agar mereka dapat mengakses pendidikan secara gratis, ternyata tidaklah demikian. Pada prakteknya, selama bersekolah anak-anak korban Lumpur Lapindo masih dikenakan biaya seragam, buku, daftar ulang, sumbangan uang gedung, ujian, pengambilan raport, dan sebagainya.

Selama ini, baik pemerintah maupun pihak Lapindo tampaknya sudah berupaya untuk menyelesaikan persoalan yang menimpa masyarakat, tetapi kelihatannya hanya sibuk mengurusi ganti rugi. Hasilnya pun hingga saat ini tak kunjung selesai. Di sisi lain, masalah anak putus sekolah korban lumpur Lapindo (APSKLL) belum mendapat perhatian, padahal dikhawatirkan mereka sangat rentan menjadi anak-anak nakal. Mereka memiliki waktu luang yang seharusnya digunakan untuk bersekolah, tetapi mungkin saja dipergunakan dengan berkumpul sesama anak yang tidak sekolah, bekerja membantu orang tua di rumah atau terpaksa bekerja untuk mencari uang demi kelangsungan 
hidup keluarganya, meskipun dengan pekerjaan yang berat. Sebuah LSM Kelompok Peduli Perempuan dan Anak Korban Lumpur (Kepak) melaporkan bahwa ada indikasi trafficking anak-anak korban lumpur di Porong yang dijadikan pekerja seks komersial (PSK) di kawasan lokalisasi Tretes, Kecamatan Prigen, Pasuruan. Anak-anak tersebut berasal dari Kelurahan Jatirejo, Kecamatan Porong. Sebelum terjebak dalam dunia prostitusi, mereka diiming-imingi akan dicarikan pekerjaan di luar kota (http://stapacenter.org/home/index.php/en/articles/93-anak-korban-lumpur lapindo-mulaidijual-jadi-psk).

Berdasarkan uraian yang telah dikemukakan di atas, maka fenomena APSKLL tidak dapat dibiarkan. Apabila masalah ini tidak segera diatasi, dikhawatirkan akan memunculkan kemiskinan, kebodohan, dan keterbelakangan. Untuk mengangkat atau mengentaskan permasalahan anak putus sekolah tersebut diperlukan suatu model pendidikan keterampilan hidup (life skills) yang sesuai dengan minat, bakat, dan keterampilan mereka. Hal ini mendesak dikaji sebagai bagian dari tanggung jawab moral akan masa depan anak Indonesia. Melalui penguasaan keterampilan hidup, diharapkan APSKLL ini mampu memperoleh penghasilan sendiri yang dapat menghidupi dirinya dan keluarganya sehingga mereka mampu keluar dari kemiskinan, keterbelakangan, dan kebodohan.

Artikel ini akan mendeskripsikan hasil penelitian yang dilaksanakan pada tahun 2013 yang dimaksudkan untuk mengembangkan model pendidikan keterampilan hidup (life skills) bagi anak putus sekolah korban lumpur Lapindo. Secara khusus artikel ini bertujuan untuk: (a) mendeskripsikan profil anak putus sekolah korban lumpur Lapindo, (b) mengidentifikasi keterampilan hidup (life skills) yang disukai dan diminati, serta (c) mengembangkan modul pendidikan keterampilan hidup bagi anak putus sekolah korban lumpur Lapindo.

\section{KAJIAN TEORITIK \\ Anak Putus Sekolah}

Terdapat berbagai pengertian mengenai putus sekolah atau drop out. Dalam kamus Besar Bahasa Indonesia disebutkan bahwa putus sekolah adalah meninggalkan sekolah sebelum tamat, berhenti sekolah, tidak dapat melanjutkan sekolah. Berdasarkan defenisi tersebut, maka yang dimaksud dengan putus sekolah adalah jika seseorang berhenti sekolah atau tidak melanjutkan pendidikan sebelum tamat tanpa menjelaskan lebih jauh mengenai tingkatannya.

Sementara itu, Badan Pusat Statistik memberi batasan mengenai putus sekolah yaitu pernah sekolah pada jenjang pendidikan tertentu tapi berhenti sekolah sebelum menamatkan jenjang pendidikannya, sedangkan anak yang berhenti di suatu jenjang pendidikan tertentu tetapi telah menamatkannya tidak dianggap sebagai putus sekolah tetapi sekedar tidak melanjutkan. Lebih lanjut, Vembriarto (1977) menyatakan bahwa putus sekolah adalah keluar dari sekolah formal sebelum berhasil menamatkan pelajarannya.

Paling tidak Indriaty (2004) mengidentifikasi ada 3 (tiga) faktor penyebab anak putus sekolah, yaitu: (1) pekerjaan dan pendapatan orang tua, (2) jumlah tanggungan keluarga, dan (3) latar belakang pendidikan orang tua. Temuan Indriaty (2004) tersebut sejalan dengan hasil penelitian Daulay \& Susilo (2012) yang menemukan bahwa pada rumahtangga yang berprofesi sebagai petani dan memiliki jumlah anak yang banyak sangat rentan mengalami putus sekolah. Dengan demikian, masalah anak putus sekolah sangat terkait dengan tingkat kesejahteraan ekonomi keluarga.

\section{Pendidikan Keterampilan Hidup}

Konsep kecakapan hidup (life skill) dirumuskan secara beragam, sesuai dengan landasan filosofis penyusunnya. Salah satu konsep kecakapan hidup dikemukakan oleh Nelson-Jones dalam 
Sumirat (2007) yang menyebutkan bahwa secara netral kecakapan hidup merupakan urutan pilihan yang dibuat seseorang dalam bidang keterampilan yang spesifik. Sumber lain memaknai kecakapan hidup sebagai pengetahuan yang luas dan interaksi kecakapan yang diperkirakan merupakan kebutuhan esensial bagi manusia untuk dapat hidup secara mandiri (Sumirat, 2007). Kecakapan hidup juga dimaknai sebagai kecakapan yang dimiliki seseorang untuk berani menghadapi problema hidup dan kehidupan secara wajar tanpa merasa tertekan, kemudian secara proaktif dan kreatif mencari serta menemukan solusi sehingga akhirnya mampu mengatasinya (Supriyanto, dkk, 2003 dalam Rubiyanto, dkk, 2013).

Berdasarkan batasan-batasan tersebut, maka pendidikan keterampilan hidup dapat dipahami sebagai pendidikan untuk meningkatkan kemampuan, kesanggupan, dan keterampilan yang diperlukan oleh seseorang untuk menjaga kelangsungan hidup dan pengembangan dirinya (Depdiknas, 2002). Kemampuan adalah realisasi dari kecakapan hidup yang bersifat kognitif (mengetahui cara mengerjakan); kesanggupan adalah realisasi dari kecakapan hidup yang lebih bersifat afektif (kemauan atau dorongan untuk berperilaku); dan keterampilan adalah realisasi dari kecekapan hidup yang bersifat psikomotorik (tindakan yang dilakukan atas dasar pengetahuan dan kemauan).

Menurut Supriatna (2013), keterampilan hidup dapat dipilah menjadi lima, yaitu: (1) keterampilan hidup mengenal diri (self awarenes) atau kemampuan hidup personal (personal skill) yang mencakup: (a) penghayatan diri sebagai makhluk Tuhan, anggota masyarakat, dan warga negara, serta (b) menyadari dan mensyukuri kelebihan dan kekurangan yang dimiliki; (2) keterampilan berfikir rasional (thinking skill) yang mencakup: (a) kecakapan menggali dan menemukan informasi, (information searching), (b) kecakapan mengolah informasi dan mengambil keputusan (information searching and decision skills), (c) kecakapan memecahkan masalah secara kreatif (creative problem solving skill), (3) keterampilan sosial (social skill) yang mencakup: (a) kecakapan komunikasi dengan empati (communication skill) dan (b) kecakapan kerjasama (collaboration skill); (4) keterampilan akademik (academik skill) atau kemampuan berfikir ilmiah, serta (5) keterampilan vokasi (vocational skill) yang merupakan keterampilan yang dikaitkan dengan bidang pekerjaan tertentu yang terdapat di masyarakat. Dalam konteks penelitian ini, keterampilan yang dimaksud berorientasi pada keterampilan vokasi (vocational skill).

Secara sosiologis, vocational life skill merupakan suatu bentuk investasi sosial, yaitu strategi yang mengalokasikan anggaran publik untuk program-program pemberdayaan dan pendidikan karena anak-anak merupakan calon tenaga kerja di masa mendatang, sehingga dengan menyiapkan mereka sejak dini maka di masa mendatang akan lahir tenaga-tenaga kerja yang berkualitas dan memiliki daya saing global. Konsep investasi sosial dikembangkan Giddens (1998) untuk memajukan kesejahteraan agar setiap individu dan kelompok dapat berkontribusi bagi penciptaan kesejahteraan. Asumsinya, menurut Giddens, melalui program-program investasi sosial, pemerintah dapat mengembangkan masyarakat untuk merespons dan beradaptasi dengan perubahan ekonomi global yang selanjutnya meningkatkan daya saing masyarakat.

\section{METODE PENELITIAN}

Penelitian ini menggunakan pendekatan penelitian dan pengembangan. Penelitian di lakukan di enam desa yang dipilih secara purposif sampling dengan pertimbangan keenam desa tersebut memiliki anak putus sekolah. Data dikumpulkan melalui wawancara mendalam dengan informan yaitu; pejabat pemerintah (Dinas Pendidikan Kabupaten Sidoarjo, BPLPS, Kepala Desa, dan pengurus Sanggar AIFaz). Peneliti melakukan wawancara dengan informan untuk mendapatkan 
informasi tentang sebaran anak putus sekolah di masing-masing desa. Hasil wawancara dikumpulkan dan dianalisis dengan teknik persentase dan rata-rata (statistik deskriptif). Selanjutnya, untuk mendapatkan profil dan kebutuhan jenis pendidikan keterampilan hidup bagi anak putus sekolah korban lumpur Lapindo (APSKLL), peneliti mewawancarai 67 ASPKLL dan dilengkapi dengan pengisian kuesiner. Hasil wawancara dikumpulkan dan dianalisis dengan teknik deskriptif (persentase dan rata-rata) serta analisis data kualitatif model Miles dan Huberman (1992).

Pengembangan model pendidikan keterampilan hidup diperoleh dengan menggunakan metode Penelitian dan Pengembangan (Research and Development -R\&D). Alasan memilih metode R\&D adalah karena metode ini: (1) digunakan untuk menghasilkan model tertentu; (2) cocok untuk pengembangan bidang-bidang yang terkait dengan teknologi diklat; (3) untuk mengembangkan model. Prosedur R\&D memodifikasi model Plomp (1997) yang meliputi lima tahap yaitu: (1) penelitian awal; (2) perancangan; (3) realisasi/konstruksi; (4) tes, evaluasi dan revisi; dan (5) implementasi. Sesuai dengan tujuan penelitian untuk menemukan model pendidikan keterampilan hidup, maka penelitian ini hanya terfokus pada tahap 1 sampai 3. Alur tahapan penelitian dapat dilihat pada Gambar 1.

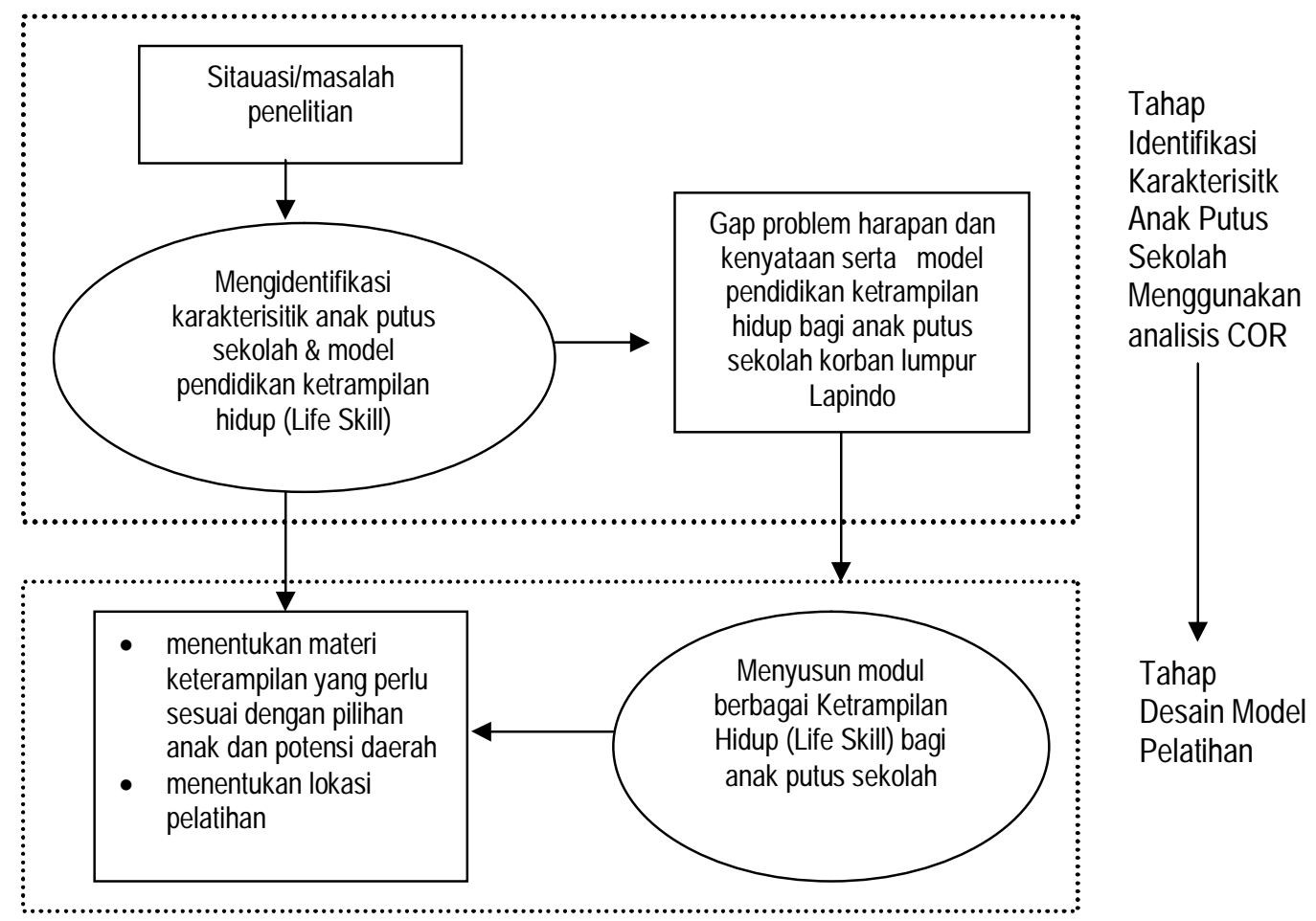

Gambar 1. Alur pengembangan model pendidikan keterampilan hidup

Berdasarkan alur tersebut di atas, peneliti merancang tahap-tahap penelitian sebagai berikut. Pertama, tahap awal, identifikasi data dasar mengenai karakteristik anak putus sekolah yang meliputi jumlah, alamat tempat tinggal, umur anak putus sekolah, lamanya putus sekolah, tingkat pendidikan anak putus sekolah, ungkapan perasaan setelah putus sekolah, alasan anak putus sekolah, dan potensi/model pendidikan ketrampilan hidup yang diinginkan. Kedua, tahap desain (perancangan) model. Ketiga, tahap realisasi penyusunan modul berbagai keterampilan hidup (life skill) bagi anak 
putus sekolah korban lumpur Lapindo, melalui modul pendidikan dan pelatihan. Data model pendidikan keterampilan hidup dalm bentuk modul diklat dianalisis secara kualitatif menggunakan model Miles dan Huberman (1992). Desain penelitian kualitatif bersifat sementara (emergent) yaitu dapat diubah-ubah sesuai realitas sosial di lapangan.

Berdasarkan alur tersebut di atas, peneliti merancang tahap-tahap penelitian sebagai berikut. Pertama, tahap awal, identifikasi data dasar mengenai karakteristik anak putus sekolah yang meliputi jumlah, alamat tempat tinggal, umur anak putus sekolah, lamanya putus sekolah, tingkat pendidikan anak putus sekolah, ungkapan perasaan setelah putus sekolah, alasan anak putus sekolah, dan potensi/model pendidikan ketrampilan hidup yang diinginkan. Kedua, tahap desain (perancangan) model. Ketiga, tahap realisasi penyusunan modul berbagai keterampilan hidup (life skill) bagi anak putus sekolah korban lumpur Lapindo, melalui modul pendidikan dan pelatihan. Data model pendidikan keterampilan hidup dalm bentuk modul diklat dianalisis secara kualitatif menggunakan model Miles dan Huberman (1992). Desain penelitian kualitatif bersifat sementara (emergent) yaitu dapat diubah-ubah sesuai realitas sosial di lapangan.

Pemilihan informan bersifat bola salju (snow-ball) yaitu informan bertambah terus sampai informasi yang didapat jenuh (redundancy). Instrumen penelitian adalah peneliti sendiri (human instrument). Pengumpulan data menggunakan pendekatan inkuiri naturalistik. Upaya peningkatan kredibilitas hasil penelitian dicapai melalui teknik trianggulasi yang meliputi; (1) sumber data, (2) pengumpulan data, (3) teori/kepustakaan, dan (4) metode pengumpulan data. Triangulasi sumber data dilakukan dengan cara mencari data dari banyak informan, yaitu dari anak-anak putus sekolah, aparat Dinas Pendidikan, Dinas Sosial dan Tenaga Kerja, pihak Sekolah, orang tua, Kepala Desa, dan tokoh masyarakat. Sementara itu, triangulasi pengumpulan data dilakukan dengan menggunakan orang lain sebagai pembantu pengumpul data. Triangulasi teori dilakukan dengan cara mengkajinya dari berbagai teori yang relevan dan para ahli sehingga dalam hal ini tidak digunakan teori tunggal tetapi bersifat jamak. Sedangkan triangulasi metode dilakukan dengan menggunakan bermacam-macam metode pengumpulan data (observasi, interview, studi dokumentasi, dan focus group discussion).

\section{HASIL DAN PEMBAHASAN}

\section{A. Profil Anak Putus Sekolah Korban Lumpur Lapindo}

Sidoarjo yang dibahas dalam studi ini adalah Sidoarjo masa kini dengan berbagai potensi masyarakat dan sosial, politik dan ekonominya. Namun demikian, tetap tidak dapat diingkari bahwa Sidoarjo yang sekarang merupakan perjalanan sejarah yang Jenggala sebagai pewaris kerajaan Kahuripan yang dalam perjalanannya sering dan bahkan selalu beroposisi dengan Daha/Kediri. Tidaklah mengherankan jika Kabupaten Sidoarjo selama ini berjalan dengan kemajuan yang cukup pesat, baik dalam bidang pertanian, perikanan dan bahkan perindustrian. Kemajuan tersebut terkait erat dengan letak Sidoarjo yang berada di Delta Sungai Berantas sehingga memiliki tanah pertanian yang subur dan dikenal sebagai penghasil komoditi pertanian seperti padi, tebu, dan kacangkacangan. Disamping itu, keberadaan selat Madura di sebelah timur menjadi potensi yang cukup besar terutama produk udang dan kepiting, sehingga kedua produk laut ini menjadi simbol kebanggaan kabupaten Sidoarjo.

Berdasarkan aspek sejarah, kawasan Sidoarjo umumnya dan Porong, Tanggulangin khususnya, sudah lama dikenal dan dijuluki sebagai "tanah yang hilang", yang terkubur lebih dari 5 $\mathrm{km}$. Terdapat dua buah sungai yang mengalir di bawah tanah yang menimbulkan gas di muara, di Selat Madura, tepatnya di Bangkalan dan Gununganyar (Widodo, Amin. 2007). Wilayah ini 
mengandung potensi yang berbahaya akibat kandungan migas di sungai purba yang kaya leburan mahkluk bumi di masa lalu. Antara lain berupa semburan gas dan percikan api di permukaan bila tergali. Oleh karena itu ketika Belanda menduduki wilayah tersebut, tidak ingin terlibat dengan masalah yang bisa menyengsarakan, dan melarang adanya pengeboran di wilayah itu (Mangoenpoerojo, 2008). Atas dasar inilah, muncul pendapat yang menyatakan bahwa munculnya semburan lumpur bukan bencana alam, tetapi kesalahan PT Lapindo yang melakukan pengeboran minyak yang tidak sesuai prosedur.

Terlepas dari kontroversi tentang penyebab munculnya lumpur Lapindo, yang jelas kini kabupaten Sidoarjo memiliki beban berat dan kemunduran perekonomian. Setidaknya terdapat tiga kecamatan yang mengalami dampak yang paling serius dari semburan lumpur Lapindo, yaitu wilayah kecamatan Porong, kecamatan Tanggulangin, dan kecamatan Jabon. Pada umumnya warga di tiga kecamatan tersebut adalah petani dan buruh tani, tetapi kini sudah tidak dapat lagi melakukan kegiatan rutin mencari nafkah dengan keahliannya tersebut. Mereka juga terpaksa harus melakukan migrasi ke daerah lain. Migrasi terpaksa petani korban lumpur Lapindo ke tempat baru membawa perubahan yang signifikan pada proses dan struktur masyarakat. Masyarakat tidak memiliki pekerjaan dan menganggur, hidup dengan mengandalkan uang pinjaman kepada para sanak saudara. Akibatnya, banyak orang tua yang tidak mampu membiayai pendidikan anak-anaknya sehingga mereka harus berhenti atau putus sekolah.

Adanya gejala anak putus sekolah sebagai bagian dari dampak lumpur Lapindo tidak dapat dibiarkan terus menerus. Hal ini disebabkan anak-anak merupakan masa depan bangsa yang akan menggantikan tahapan kepemimpinan banga. Untuk itu, perlu diberikan pendidikan keterampilan hidup agar mereka memiliki keterampilan yang dapat berguna dimasa yang akan datang. Melalui penguasaan keterampilan hidup, diharapkan anak putus sekolah ini mampu memperoleh penghasilan sendiri yang dapat menghidupi dirinya dan keluarganya sehingga mampu keluar dari kemiskinan, keterbelakangan, dan kebodohan.

Temuan data menunjukkan dari 67 orang APSKLL yang berhasil dijaring melalui wawancarai dan pengisian kuesioner ternyata berasal dari enam desa, yaitu Desa Renojaya, Siring, Besuki, Pejarakan, Kedungbendo, dan Sentul. Diantara enam desa tersebut, tampaknya jumlah anak putus sekolah yang paling banyak berasal dari Desa Besuki yaitu sebanyak 20 orang $(29,90)$, disusul Desa Renojaya sebanyak 15 orang (22,39\%). Sementara itu, desa yang paling minim memiliki APSKLL adalah Desa Kedungbendo yaitu sebanyak 5 orang (7,46\%). Selengkapnya jumlah anak putus sekolah berdasarkan asal desa dan jenis kelamin dapat dilihat pada Tabel 1.

Tabel 1. Profil Anak Putus Sekolah Berdasarkan Asal Desa dan Jenis Kelamin

\begin{tabular}{|c|c|c|c|c|c|c|c|}
\hline \multirow{2}{*}{ Kecamatan } & \multirow{2}{*}{ Desa } & \multicolumn{4}{|c|}{ Jenis Kelamin } & \multirow{2}{*}{ Jlh } & \multirow{2}{*}{$\%$} \\
\hline & & $L$ & $\%$ & $P$ & $\%$ & & \\
\hline \multirow[t]{2}{*}{ Porong } & Renojaya & 10 & 27,10 & 5 & 16,66 & 15 & 22,39 \\
\hline & Siring & 5 & 13,50 & 2 & 6,67 & 7 & 10,44 \\
\hline \multirow[t]{2}{*}{ Jabon } & Besuki & 8 & 21,60 & 12 & 40,00 & 20 & 29,90 \\
\hline & Pejarakan & 4 & 10,80 & 5 & 16,67 & 9 & 13,40 \\
\hline \multirow[t]{3}{*}{ Tanggulangin } & Kedungbendo & 3 & 8,10 & 2 & 6,67 & 5 & 7,46 \\
\hline & Sentul & 7 & 18,90 & 4 & 13,33 & 11 & 16,41 \\
\hline & & 37 & 100 & 30 & 100 & 67 & 100 \\
\hline
\end{tabular}

Sumber : Data Penelitian, 2013 
Tabel 1 menunjukkan bahwa dilihat dari asal desa ternyata anak putus sekolah korban lumpur Lapindo mayoritas berasal dari desa Besuki yaitu 20 orang (29,90\%) dan desa Renojaya sebanyak 15 orang (22,39\%). Temuan penelitian ini sangat terkait dengan persoalan ganti rugi tanah dan bangunan rumah yang dijanjikan pemerintah terhadap masyarakat korban lumpur. Hal ini terlihat dari masyarakat yang berasal dari desa Renokenongo sudah memperoleh ganti rugi meskipun masih 75\%. Sementara itu, desa Besuki Barat dan Timur (dipisah oleh jalan Tol), ternyata menurut Perpres No. 40 tahun 2009, Desa Besuki Timur tidak termasuk yang memperoleh ganti rugi. Padahal kedua wilayah tersebut sama-sama merasakan sebagai korban dari luberan lumpur Lapindo. Posisi wilayah tersebut juga dikhawatirkan akan berdampak negatif terhadap integrasi sosial kemasyarakatan, seperti adanya kecemburun sosial yang berujung pada konflik horizontal.

Selanjutnya, sebaran jenis kelamin responden menunjukkan dari 67 orang responden, ternyata 37 orang laki-laki, dan sisanya 30 orang adalah perempuan. Perbandingan jenis kelamin tiap desa adalah sebagai berikut; Desa Basuki memiliki jumlah responden perempuan 12 orang $(29,90 \%)$ dan 8 orang $(21,60 \%)$ laki-laki, desa Renojaya sebanyak 10 orang $(27,10 \%)$ laki-laki dan 5 orang $(16,66 \%)$ perempuan, desa Sentul sebanyak 7 orang $(18,90 \%)$ laki-laki dan 4 orang $(13,33 \%)$ perempuan, di desa Pejarakan sebanyak 4 orang $(10,80 \%)$ laki-laki dan 5 orang $(16,67 \%)$ perempuan, desa Siring terdapat 5 orang $(13,50 \%)$ dan 2 orang $(6,67 \%)$ perempuan, dan desa Kedungbendo terdapat 3 orang $(8,10 \%)$ laki-laki dan 2 orang $(6,67 \%)$ perempuan.

Kemudian berdasarkan usia, ternyata dari 67 orang responden diketahui mayoritas berusia antara usia 16 sampai usia 18 tahun yakni 39 orang (58,20\%) dari total anak putus sekolah yang ada. Berusia antara13 sampai 15 tahun merupakan urutan kedua yakni 23 orang $(34,32 \%)$ dan usia 7 sampai 12 tahun sebanyak 5 orang $(7,44 \%)$ dari jumlah anak putu sekolah yang ada.Secara grafis data sebaran anak putus sekolah berdasarkan rentang usia dan asal desa dapat dilihat pada Gambar 2.

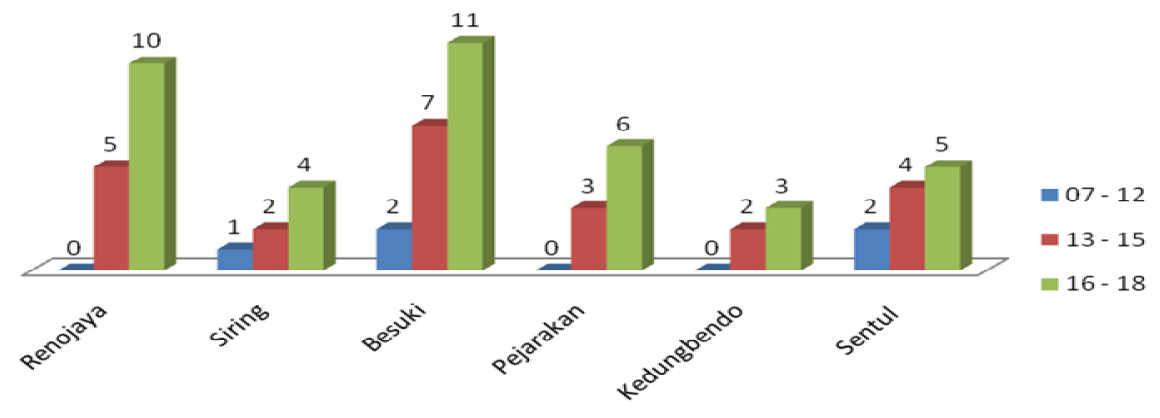

Gambar 2. Grafik usia anak putus sekolah korban lumpur Lapindo

Berdasarkan gambar 2 terlihat bahwa anak putus sekolah dengan rentang usia 16-18 tahun merupakan jumlah terbanyak pada tiap-tiap desa di wilayah penelitian. Terbukti di Desa Renojaya terdapat 10 orang (25,64\%), Desa Siring terdapat 4 orang (10,25\%), Desa Besuki 11 orang (28,21\%), Desa Pejarakan terdapat 6 orang (15,38\%), Desa Kedungbendo terdapat 3 orang (7,70\%), dan Desa Sentul terdapat 5 orang (12,82\%).

Selanjutnya dari sisi pendidikan menunjukkan bahwa sedikitnya terdapat 11 orang $(16,41)$ lulusan SD atau sederajat, 26 orang $(38,80 \%)$ lulusan SMP atau sederajat, dan selebihnya 30 orang 
$(44,78 \%)$ merupakan lulusan SLTA atau sederajat. Lebih jelasnya jumlah anak putus sekolah korban lumpur Lapindo dilihat dari jenjang pendidikan dapat dilihat pada Gambar 3.



Gambar 3. Grafik pendidikan anak putus sekolah korban lumpur Lapindo

Gambar 3 menunjukkan bahwa mayoritas anak putus sekolah di tingkat SMA. Hal ini menunjukkan bahwa rata-rata mereka sudah pernah mengenyam pendidikan tingkat SMP, tetapi terpaksa tidak melanjutkan ke SMA. Berdasarkan hasil wawancara dengan pengurus Sanggar AlFaz, di desa Besuki hampir setiap tahun ajaran baru terjadi peningkatan anak-anak yang putus sekolah. Hal ini disebabkan orang tua mereka tidak mampu membiayai pendidikan, seperti pembelian seragam, tas, buku dan sebagainya. Rata-rata anak putus sekolah di Desa Besuki ádalah lulusan SLTP, karena sekolah SMA tidak tersedia sehingga anak-anak yang ingin melanjutkan pendidikan SMA harus ke kota kecamatan yang letaknya jauh dari tempat mereka.

Lebih lanjut, pengurus sanggar Al-Faz menyatakan bahwa sebagian besar anak putus sekolah menghabiskan waktunya untuk bekerja meskipun pekerjaan yang dilakukan dalam bentuk kategori yang berat. Hal ini dilakukan untuk menambah pendapatan ekonomi keluarga karena jika anak tidak terlibat dalam membantu ekonomi maka kebutuhan keluarga tidak terpenuhi. Hasil wawancara dengan orang tua menunjukkan bahwa pemanfaatan tenaga kerja keluarga termasuk tenaga kerja anak merupakan suatu kebutuhan yang tidak dapat ditawar-tawar lagi. Meskipun sebenarnya upaya anak untuk membantu orang tua dengan terlibat bekerja menemui hambatan karena setelah munculnya lumpur Lapindo tidak banyak lapangan kerja yang tersedia. Anak-anak yang tidak bersekolah lagi bekerja sebagai juru wisata danau lumpur, jualan VCD, kaos lumpur Lapindo, dan ada juga yang bekerja sebagai tukang ojek.

Temuan data ini menunjang hasil penelitian Sumarmi dan Daulay (2009) yang menemukan bahwa salah satu mekanisme yang dilakukan rumahtangga korban lumpur Lapindo adalah dengan memanfaatkan wisata lumpur Lapindo sebagai usaha jasa yang menjanjikan. Setelah munculnya kasus lumpur Lapindo ternyata hampir setiap hari ada saja pengunjung yang datang ke lokasi tersebut, bahkan diantaranya ada yang berasal dari luar negeri. Kondisi inilah yang dimanfaatkan oleh anak-anak yang tidak sekolah lagi untuk mencari penghidupan dengan cara membuka jasa usaha di sekitar wisata tersebut. Nasib yang sedikit beruntung dialami oleh anak-anak putus sekolah pada jenjang SMA atau sudah lulus SMA. Berbekal ijazah SMA sebagian dari mereka diterima sebagai buruh di pabrik, namun lokasi pabrik yang sangat jauh dari tempat tinggal mereka saat ini. 


\section{B. Pilihan Keterampilan Hidup (Life Skill)}

Berdasarkan hasil wawancara dan FGD dengan, orang tua, tokoh masyarakat, dan aktivis sosial yang ada di Sanggar Al-Fadz Desa Besuki sangat mendukung rencana pelatihan keterampilan hidup bagi anak putus sekolah korban lumpur Lapindo. Dalam kegiatan FGD terungkap pula salah seorang aktivis sosial anak yang mengusulkan agar kegiatan yang akan dilakukan tidak saja bagi anak-anak yang sudah putus sekolah, tetapi bagi anak yang rawan putus sekolah juga diberikan pelatihan keterampilan. Adapun jenis-jenis keterampilan hidup yang paling banyak diminati oleh anak putus sekolah korban lumpur Lapindo adalah keterampilan service sepeda, yakni 27 orang $(40,28 \%)$, keterampilan menjahit yakni 24 orang $(35,82 \%)$, dan keterampilan service ponsel menempati urutan ketiga yakni 16 orang (23,90\%), dan hanya satu orang (1,50\%) yang memilih keterampilan home industriy. Secara sederhana jika dilihat secara grafis pilihan keterampilan hidup (life skill) anak putus sekolah korban lumpur Lapindo akan nampak dalam gambar 4.

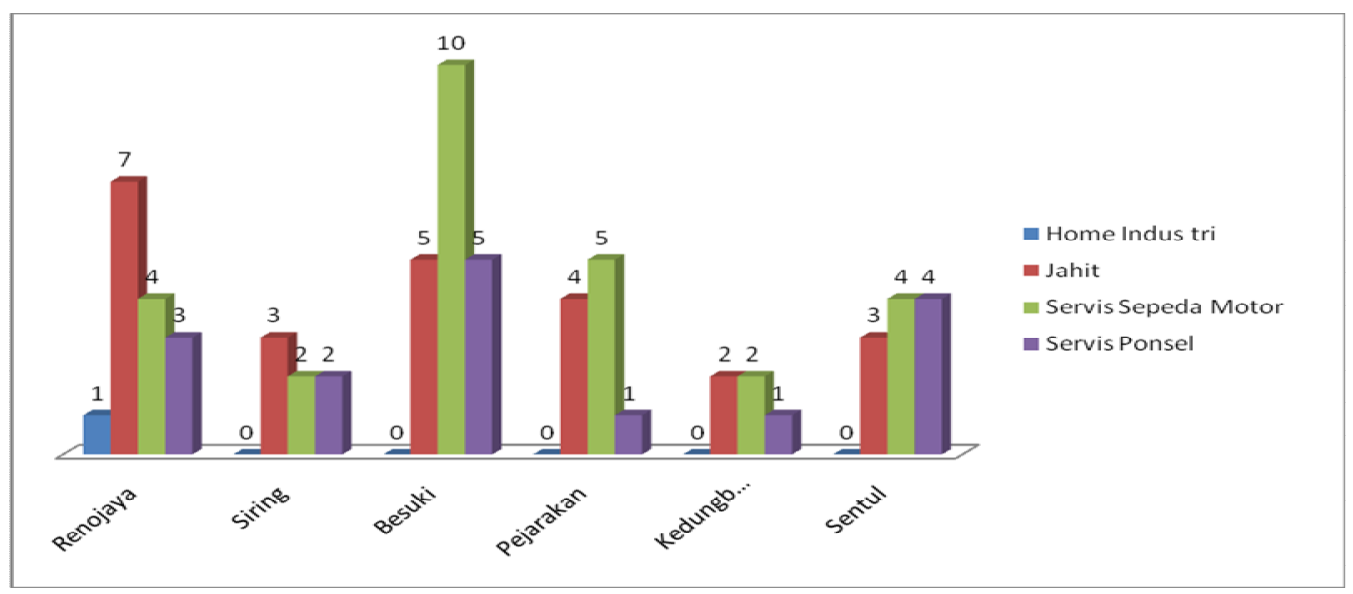

Gambar 4. Pilihan jenis keterampilan anak putus sekolah

Berdasarkan hasil penyebaran kuesioner menunjukkan bahwa anak putus sekolah korban lumpur Lapindo memilih 4 jenis keterampilan hidup yang diinginkan. Namun, dari empat jenis keterampilan yang dipilih ternyata keterampilan service sepeda motor memiliki kecenderungan yang paling banyak dipilih oleh anak-anak. Berdasarkan hasil wawancara dan FGD, dapat diketahui alasan anak-anak putus sekolah memilih keterampilah service sepeda motor, yaitu: (1) sepeda motor yang akan diservis bukan hanya berasal dari Kabupaten Sidoarjo saja tetapi juga dari kabupaten lain yang melintasi wilayah Sidoarjo; (2) sepeda motor ada masa pakainya sehingga harus diservis secara berkala; (16) tiap keluarga baik kaya maupun miskin sudah memiliki sepeda motor; (3) dengan modal Rp 200.000 sudah dapat membawa pulang motor kredit; (18) biaya perjalanan dengan sepeda motor lebih irit; (4) keterampilan servis sepeda motor bermanfaat minimal mampu menservis motor sendiri dan membuka usaha bengkel sepeda motor.

Beberapa alasan yang dikemukakan di atas mendukung temuan penelitian Ndy, dkk. (2011) yang dikutip oleh Usman dkk (2012) dalam artikelnya berjudul Model Diklat Kewirausahaan bagi Remaja Putus Sekolah. Ndy, dkk. menyatakan bahwa tahun 2010 jumlah sepeda motor di Jabodetabek bertambah 1,5 juta unit. Penambahan jumlah sepeda motor ini terjadi pula beberapa daerah lain termasuk di Provinsi Jawa Timur, lebih khusus di kabupaten Sidoarjo. Pilihan warga 
Jabodetabek menggunakan sepeda motor karena kondisi angkutan umum sangat buruk. Kondisi angkutan umum di Jabodetabek tidak jauh berbeda dengan kondisi angkutan umum di Kabupaten Sidoarjo. Temuan Ndy, dkk. (2011: 25) adalah banyak penumpang angkutan umum pindah ke sepeda motor karena lebih mudah, murah, praktis, dan cepat sampai tujuan.

Penelitian Caesar Alexey, dkk. (2011: 35), banyaknya pengguna angkutan umum beralih ke sepeda motor dipicu oleh kemudahan mendapatkan kredit sepeda motor. Sepeda motor seharga Rp12,5 juta hanya dengan uang muka Rp 400 ribu dengan cicilan bervariatif tergantung lamanya angsuran. Temuan ini tidak jauh berbeda dengan kemudahan mengangsur sepeda motor yang terjadi di Jawa Timur. Namun, menurut Caesar Alexey dkk. (2011:25), "ada risiko kecelakaan fatal di balik biaya transportasi murah, kecepatan, kepraktisan, serta kemudahan memiliki sepeda motor. Jumlah sepeda motor yang terlalu banyak dan perilaku berlalu lintas yang buruk membuat risiko kecelakaan." Salah satu strategi untuk menanggulangi berbagai dampak yang muncul dibutuhkan pemeliharaan berkala terhadap alat transportasi tersebut. Permasalahannya ádalah jumlah bengkel sepeda motor belum seimbang dengan pertumbuhan kendaraan roda dua.

Studi yang dilakukan oleh APINDO menggambarkan bahwa otomotif sepeda motor memiliki prospek yang cukup bagus dalam menyerap tenaga kerja kaum muda. Dengan demikian sektor otomotif mampu menjadi alternatif solusi dalam mengatasi pengangguran di Indonesia. Jumlah pengangguran terutama kaum muda (usia 15-24 tahun) yang mencapai 60\% dari total agregat pengangguran di Indonesia yang mencapai 11,6 juta tahun 2007, sedikit banyak menggambarkan bahwa dunia pendidikan dan pelatihan belum sepenuhnya mendukung kebutuhan dunia industri. Hasil wawancara dengan anak-anak putus sekolah korban lumpur lapindo ternyata tidak berbeda jauh dengan temuan penelitian APINDO, dimana anak-anak putus sekolah tersebut terpaksa menjadi pengangguran karena sulitnya memperoleh pekerjaan yang layak, sementara pengetahuan yang diterima sewaktu di bangku sekolah ternyata kurang sesuai dengan kebutuhan lapangan kerja. Sekali lagi temuan ini memperkuat hasil penelitian Daulay dan Susilo (2012) yang menemukan bahwa orang tua dari anak putus sekolah korban lumpur Lapindo yang memiliki pandangan anak-anak mereka lebih baik tidak usah sekolah karena lulusan sarjana sekali pun saat ini sulit mencari kerja, lebih baik anak tidak usah sekolah tinggi-tinggi agar bisa langung bekerja dan mendapatkan uang.

Pilihan keterampilan yang kedua adalah keterampilan menjahit. Pilihan keterampilan menjahit ini kemungkinan dipilih oleh anak-anak putus sekolah yang berjenis kelamin perempuan. Berdasarkan hasil wawancara dan FGD diketahui berbagai alasan mereka memilih keterampilan menjahit, diantaranya, (1) semua masyarakat pasti membutuhkan pakaian, oleh karena itu profesi tukang jahit pasti dibutuhkan, (2) pekerjaan tukang jahit tidak lekang dengan usia karena sepanjang masih mampu bekerja pasti dicari dan tetap dibutuhkan, (3) untuk membuka usaha sendiri tidak memerlukan modal yang banyak, (4) sekiranya tidak diterima bekerja di pabrik konvensi dapat membuka usaha sendiri, (5) dengan memiliki keterampilan menjahit, dapat menjahit baju sendiri sehingga tidak perlu lagi mengeluarkan ongkos menjahit baju.Temuan data ini mendukung penelitian Moerdiyanto (2009) yang melakukan penelitian tentang pengembangan model pendidikan kewirausahaan bagi remaja putus sekolah korban gempa sebagai usaha pengentasan kemiskinan. Remaja putus sekolah memiliki masalah yang selalu dihadapi adalah masih menganggur dan mereka menghendaki wirausaha di bidang perdagangan 21\%, agraris 19\%, dan bisnis di bidang jasa. Untuk bisnis di bidang jasa salah satu jenis keterampilan yang ingin dikembangkan oleh remaja putus sekolah yang berjenis kelamin perempuan adalah keterampilan menjahit.

Sementara itu, pilihan ketiga adalah keterampilan service ponsel (handphone). Dewasa ini memang ponsel merupakan media komunikasi yang saat ini cukup populer dan paling banyak 
penggunannya. Tidaklah mengherankan jika mulai dari anak-anak sampai orang tua memiliki handpone. Ketertarikan masyarakat memiliki handphone karena berbagai fasilitas yang ditawarkan dapat mendukung untuk berkomunikasi dengan mudah dan lancar. Salah satu fasilitas yang paling digemari adalah SMS karena harganya yang murah dan efisien. Namun, demikian perangkat handphone memiliki kelemahan, di antaranya mudah rusak karena terbuat dari bahan-bahan elektronik dan untuk saat ini masih jarang service handphone. Oleh karena itu, usaha service handphone ini sangat prospektif terutama jika dikembangkan di Provinsi Jawa Timur khususnya di Kabupaten Sidoarjo yang memiliki jumlah penduduk yang terus bertambah seiring dengan semakin banyaknya pembukaan perumahan di sekitar Sidoarjo. Untuk itulah, keterampilan service handphne perlu diberikan kepada anak-anak putus sekolah korban lumpur Lapindo agar mereka dapat mengembangkan usaha service handphne di sekitar Sidoarjo.

\section{Pengembangan model pendidikan keterampilan hidup}

Berdasarkan pemetaan jenis keterampilan yang ditanyakan kepada anak putus sekolah di lokasi penelitian, ternyata ada empat jenis keterampilan yang dipilih, yaitu service sepeda motor, service ponsel, menjahit, dan home industri. Namun, untuk kepentingan penelitian ini, model pendidikan keterampilan hidup yang dikembangkan dalam bentuk modul pelatihan hanya tiga jenis, yaitu modul service sepeda motor, modul service handphone, dan modul menjahit.

Penulisan modul dibuat sesederhana mungkin agar mudah dipahami oleh APSKLL. Sistematika modul yang disusun mengacu kepada pendapat Jamaluddin (2009), yang berisi berisi: A. Tujuan Materi. B. Materi. C. Metode. D. Evaluasi. E. Lampiran (pre-test, tugas individual, tugas kelompok, penyajian hasil diskusi, peguatan fasilitator, dan post-test). Pemilihan kata disesuaikan dengan tingkat pendidikan APSKLL agar mudah dipahami. Isi materi dipilih yang paling mendasar pilihan kata disesuaikan dengan tingkat pendidikan APSKLL agar mudah dipahami. Isi materi dipilih yang paling mendasar dan bermanfaat untuk berwirausaha. Ilustrasi berupa contoh dan gambargambar dibuat contoh nyata dan gambar yang jelas, jika mungkin gambarnya tiga dimensi. Jumlah lembar juga dibatasi seminimal mungkin karena waktunya yang relatif singkat. Di samping itu, untuk menghindarkan rasa takut di kalangan peserta jika modulnya tampak tebal. Terlebih-lebih anak putus sekolah biasanya sudah enggan membaca yang memerlukan waktu relatif lama.

Selanjutnya, dari hasil identifikasi melalui metode wawancara mendalam (in-depth interview) dengan para pelaku industri di Surabaya dan Sidoarjo terkait dengan prospek keterampilan sepeda motor, didapatkan fakta dan data bahwa kemampuan yang paling banyak dibutuhkan menyangkut tiga hal, yaitu: operator mesin (machining), operator pengelasan (welding), dan mekanis praktis. Untuk itulah modul yang dikembangkan memperhatian ketiga kebutuhan tersebut.

Disamping itu, isi modul perlu juga disisipkan materi tentang manajemen perubahan agar APSKLL mau dan mampu mengubah pola pikir, pola rasa, dan pola sikap untuk berwirausaha. Manurut Schramm (2010) manajemen perubahan diharapkan mampu membentuk adanya perubahan dari diri sendiri untuk bekerja sendiri bukan bekerja kepada orang lain. Modul pendidikan keterampilan hidup tidak ada gunanya jika peserta diklat tidak mau mengubah dirinya sendiri dari bekerja dengan orang lain menjadi bekerja Sendiri (Schramm, 2010). Untuk itu, materi kewirausahaan juga dimasukkan dalam modul agar APSKLL memahami ciri-ciri wirausaha yang sukses dan mengetahui serta menerapkan cara menjadi wirausaha yang sukses. Schramm (2010) menyatakan bahwa jika pengusaha memiliki rencana bisnis yang jelas, dipastikan usahanya pun akan berhasil. 


\section{SIMPULAN DAN SARAN \\ Simpulan}

Mendasarkan temuan-temuan penelitian di lapangan, maka dapat ditarik beberapa kesimpulan sebagai berikut.

1. Anak putus sekolah korban lumpur Lapindo di desa Renojoyo dan Siring kecamatan Porong, desa Besuki dan Pejarakan Kecamatan Jabon, dan desa Kedungbendo dan Sentul kecamatan Tanggulangin berjumlah 67 orang. Dari jumlah tersebut sebagian besar berpendidikan SLTA atau sederajat, yakni 30 orang $(44,78 \%)$, sedangkan 26 orang $(38,80 \%)$ lulusan SMP atau sederajat, dan 11 orang $(16,41 \%)$ lulusan SD atau sederajat dari total jumlah anak putus sekolah. Berdasarkan jenis kelamin ternyata 37 orang atau $52,22 \%$ berjenis kelamin pria dan sisanya 30 orang atau 44,78\% adalah berjenis kelamin wanita. Dari total 67 orang anak putus sekolah yang ada di wilayah penelitian, juga diketahui bahwa sebagian besar berusia antara 16 sampai usia 18 tahun, yakni 39 orang $(58,20 \%)$ dari total anak putus sekolah yang ada, disusul kelompok usia 13 sampai usia 15 tahun, yakni 23 orang (34,32\%), dan usia 7 sampai 12 tahun sebanyak lima orang $(7,44 \%)$ dari jumlah anak putus sekolah yang ada.

2. Jenis keterampilan yang diinginkan oleh anak putus sekolah korban lumpur Lapindo ada empat jenis, yaitu keterampilan service sepeda motor, menjahit, service handphone, dan home industry. Diantara keempat keterampilan tersebut ternyata anak putus sekolah lebih cenderung memilih service sepeda motor, yakni sebanyak 27 orang (40,28\%), disusul menjahit, yakni 24 orang $(35,82 \%)$, keterampilan service ponsel, yakni 16 orang $(23,90 \%)$, dan hanya satu orang $(1,50 \%)$ yang memilih keterampilan home industry.

3. Dalam rangka memindaklanjuti keinginan anak-anak putus sekolah korban lumpur Lapindo tersebut, saat ini sudah berhasil dikembangkan tiga modul keterampilan hidup (life skill), yakni modul service sepeda motor, modul keterampilan menjahit, dan modul service handphone. Penulisan modul dibuat sesederhana mungkin agar mudah dipahami, dengan sistematika modul mengacu kepada pendapat Jamaluddin (2009), yang berisi tujuan materi, materi, metode, evaluasi, dan lampiran (pre-test, tugas individual, tugas kelompok, penyajian hasil diskusi, peguatan fasilitator, dan post-test). Isi materi dipilih yang paling mendasar pilihan kata disesuaikan dengan tingkat pendidikan APSKLL serta dilengkapi ilustrasi berupa contoh dan gambar-gambar yang jelas. Jumlah lembar juga dibatasi seminimal mungkin untuk menghindarkan rasa takut di kalangan peserta jika modulnya tampak tebal.

\section{Saran}

Bertolak dari keterbatasan penelitian ini, perlu dilakukan penelitian lanjutan. Bidang kajian yang perlu ditindaklanjuti adalah:

1. Modul pendidikan keterampilan hidup sudah dikembangkan, namun belum dilakukan ujicoba. Oleh karena itu, bagi peneliti lain yang ingin mendalami disarankan untuk melakukan penelitian lanjutan yang bertujuan untuk menguji coba modul yang telah dikembangkan. Apabila akan digunakan secara meluas di tempat lain harus dikaji kembali terutama dari analisis kebutuhannnya dan kondisi lingkungannya.

2. Perlu mengapresiasi keinginan anak-anak putus sekolah korban lumpur Lapindo untuk segera memiliki keterampilan hidup (life skill) yang dapat dipergunakan mencari pekerjaan dan membuka usaha. Untuk itu, diharapkan pemerintah daerah untuk dapat menindaklanjutinya. 
3. Melakukan penelitian lanjutan dengan sifat saling melengkapi dan mungkin berguna bagi pemerintah dalam membuat kebijakan yang lebih berpihak pada masyarakat korban lumpur Lapindo, khususnya anak putus sekolah.

\section{REFERENSI}

Daulay. (2013). Migrasi terpaksa masyarakat korban lumpur Lapindo. Jurnal Aktual, Vol 1(1), Desember 2013.

Daulay, Pardamean \& Susilo, Singgih. (2012). Pola kehidupan dan kesempatan kerja migran petani korban lumpur Lapindo di daerah tujuan, laporan penelitian, lembaga penelitiaan Universitas Terbuka, Jakarta.

Depatemen Pendidikan Nasional. (2002).. Pola pelaksanaan pendidikan berorientasi kecakapan hidup (life skill) melalui pendekatan broad base education. Depdiknas, Jakarta.

Giddens, A. (2003). Jalan ketiga dan kritik-kritiknya. Edisi terjemahan, dari buku "The third way and its critiques", Penerjemah: Imam Khoiri. Yogyakarta: IRCiSoD.

Indriaty, Dhita (2004) Strategi adaptasi untuk mencapai aspirasi masa depan pada anak putus sekolah. Jurnal ilmu kesejahteraan sosial, vol. 3(2), September 2004.

Mangoenpoerojo, Roch Basoeki. (2008). Kerugian Bangsa Akibat Lumpur di Sidoarjo, Bandung, Visibuku Indonesia.

Miles, Matthew B. \& A. Michael Huberman. (1992). Analisis data kualitatif, Buku Sumber tentang metode-metode baru. Terjemahan dari Analyzing qualitative data: A source book for new methods. UI Press, Jakarta.

Moerdiyanto. (2009). Pengembangan model pendidikan kewirausahaan bagi remaja putus sekolah korban gempa sebagai usaha pengentasan kemiskinan di kabupaten Bantul DIY. Prosiding deseminasi hasil-hasil penelitian tingkat nasional, ISBN 978602-8429-27-6, hal.150.

Novenanto, Anton. (2008). Melihat kasus lapindo sebagai bencana sosial. Jurnal masyarakat dan kebudayaan.

Rubiyanto, Rubino, Sumarsono, Hadi, \& Ghofur, Haryanto. (2004). Model pendidikan kecakapan hidup (life skill) bagi remaja putus sekolah dalam usaha mempersiapkan diri memasuki dunia kerja melalu sinergi pemberdayaan potensi masyarakat pedesaan di wilayah kabupaten gunungkidul, diambil 30 Januari 2013 dari http:dieilib.unimus.ac.ld.

Scramm, C.J. (2010). Wirausaha tidak bisa dilatihkan, Kompas, 18 November, halaman 18.

Sumirat, D. (2007). 'Life Skill' Bidang Penyiaran Satu Solusi Atasi Pengangguran. Gemari Edisi 74/Tahun VIII/Maret 2007

Supriatna, Mamat (2013). Pengembangan kecakapan hidup di sekolah, diambil pada tanggal 25

Pebruari 2013 dari http://www.google.co.id/\#tbo=d\&output=search\&sclient=psyab\&q.

Vembriarto, St. (1977). Kapita selekta pendidikan Yogyakarta: Yayasan Penerbit.

Widodo, Amin. (2007). Misteri Gunung Lumpur dalam Gatra, 20 Juli 2007. 